\title{
Design, Thermodynamic Performance Comparison and Cost Analysis of Photovoltaic (PV), Concentrated Solar Power (CSP), Wind Turbine, Natural Gas Combined Cycle (NGCC), and Integrated Solar Combined Cycle (ISCC) Power Plants
}

\author{
Peter Jenkins, Gowtham Ramamoorthy \\ Department of Mechanical Engineering, University of Colorado, Denver, USA \\ Email: Peter.Jenkins@ucdenver.edu, Gowtham.Ramamoorthy@ucdenver.edu
}

How to cite this paper: Jenkins, P. and Ramamoorthy, G. (2020) Design, Thermodynamic Performance Comparison and Cost Analysis of Photovoltaic (PV), Concentrated Solar Power (CSP), Wind Turbine, Natural Gas Combined Cycle (NGCC), and Integrated Solar Combined Cycle (ISCC) Power Plants. Energy and Power Engineering, 12, 288-313.

https://doi.org/10.4236/epe.2020.126018

Received: May 11, 2020

Accepted: June 12, 2020

Published: June 15, 2020

Copyright $\odot 2020$ by author(s) and Scientific Research Publishing Inc. This work is licensed under the Creative Commons Attribution International License (CC BY 4.0).

http://creativecommons.org/licenses/by/4.0/

\begin{abstract}
This paper evaluates and discusses ways to use five energy resources more efficiently for generating electric power. An analysis of five different $10 \mathrm{MW}$ powerplants was made: a photovoltaic system, a concentrated solar power system, wind turbines, a natural gas combined cycle and an integrated solar combined cycle. Also, each power plant's operating principle, thermodynamic analysis, economic analysis, and simulation evaluation were made using the System Advisor Model (SAM), Engineering Equation Solver (EES), and the Thermoflow Power Plant Simulation program. From the analysis, the power plant capacity factor, grid availability, levelized cost of electricity, and annual energy production are compared and analyzed to determine a suitable power plant for a given location.
\end{abstract}

Keywords

Renewable Energy, PV, CSP, Wind Turbine, NGCC, ISCC

\section{Introduction}

In the United States, the main source of electricity generation is from coal, natural gas, and petroleum. As of 2019, 62.7 percent of electricity production is from fossil fuel, 20 percent from nuclear and 17 percent is from renewable energy [1]. Natural gas is the most dominant energy resource in the USA and nearly 
40 percent of electricity production is from natural gas. At the end of the year 2019, 1582 billion $\mathrm{kWh}$ of electricity generation was from natural gas. Natural gas produces $0.2 \mathrm{~kg} \mathrm{CO} / \mathrm{kwh}$, whereas coal produces $0.36 \mathrm{~kg}$ of $\mathrm{CO}_{2} / \mathrm{kwh}$ [2]. According to U.S. Energy Information Administration the coal share in the USA will reduce to 22 percent in 2020. The reason is partly because of the cost of the clean air requirement required to reduce the plant emissions and because other power plants like natural gas, wind and solar are getting cheaper.

On the other hand, renewable energy produces comparatively low greenhouse gas compared to fossil fuels. A wind turbine produces around $11 \mathrm{~g}$ of $\mathrm{CO}_{2}$ per $\mathrm{kWh}, \mathrm{PV}$ panels produce $12 \mathrm{~g}$ of $\mathrm{CO}_{2}$ per $\mathrm{kWh}$ and concentrated solar power produces $20 \mathrm{~g}$ of $\mathrm{CO}_{2}$ per $\mathrm{kWh}$ of electricity generated which is much less when compared to the combustion-based power plant [3]. The price of renewable energy power production per kWh has reduced drastically over the past decade. Both wind and solar energy have become competitive with natural gas. The Levelized Cost of Electricity (LCOE) for solar and wind has reduced in recent years. By the end of the year 2025, the LCOE for solar and wind will be in the range of $47-157 \$ / M W h$ and $38-83 \$ / M W h$, respectively. Alternatively, the LCOE for natural gas will increase from $50-107 \$$ /MWh to $55-126 \$ / M W h$ in the year 2025 [4]. As of 2019, the USA produces $77 \mathrm{GW}$ of electricity from solar energy, which eliminates 88 million metric tons of $\mathrm{CO}_{2}$, and $105.59 \mathrm{GW}$ of operating wind capacity [5].

\section{Outline of the Paper}

In order to determine alternative power systems that could be used in the future to provide cheaper and clean power, this paper presents the analysis of five distinct power plants each with a capacity of $10 \mathrm{MW}$. Both renewable and non-renewable energy sourced power plants have been evaluated and compared based on capital cost, LCOE, annual energy production, and the efficiency of the power plant. The power plants considered are Photovoltaic (PV), Concentrated Solar Power (CSP), Wind Turbines, Natural Gas Combined Cycle (NGCC), and Integrated Solar Combined Cycle (ISCC). To evaluate the PV, CSP and wind turbine power plants, simulations were done using the System Advisor Model (SAM). For the NGCC and ISCC power plants, a comprehensive thermodynamic analysis was done using the Engineering Equation Solver (EES) and Thermoflow Power Plant Simulation program. This paper explains the working principles of each power plant, the simulation results, the thermodynamic analysis, and the financial data for each power system.

\section{Location and Geographic Data}

The proposed $10 \mathrm{MW}$ power plant site was located in Adams County, Colorado, near the Denver International Airport as shown in Figure 1 and in the Site Data given in Table 1. The land required for the project was determined based on the type of power plant considered. 


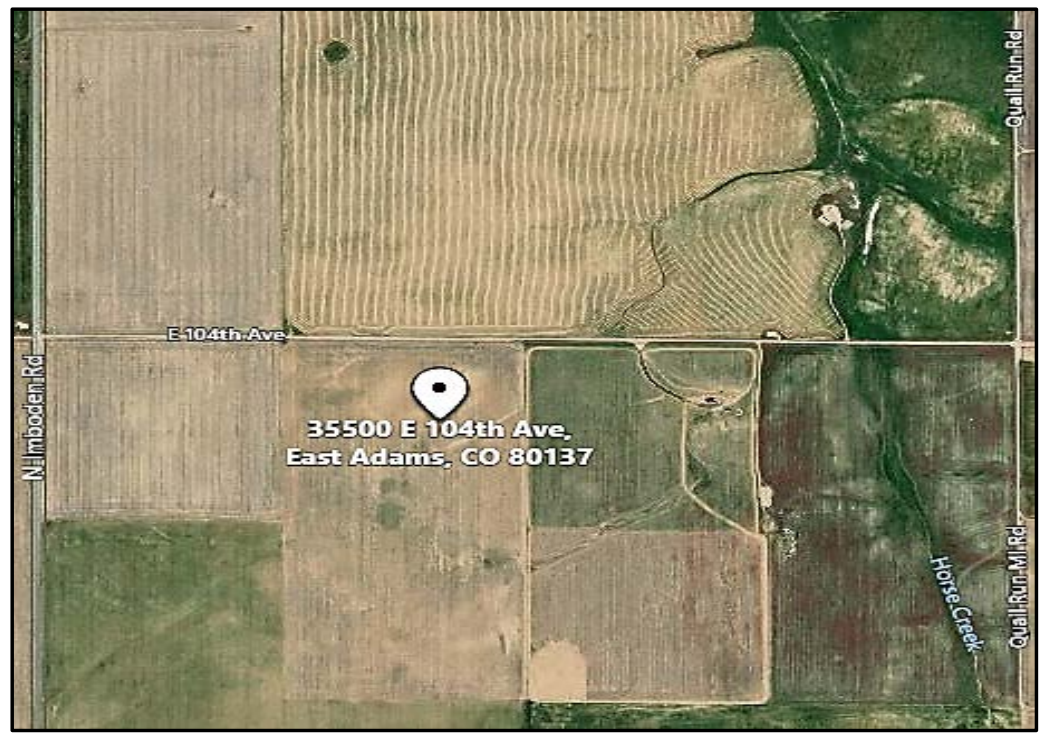

Figure 1. Site location.

Table 1. Project site data.

\begin{tabular}{cc}
\hline Latitude and longitude & $39.856337 \&-104.499534$ \\
Ground elevation & $1615 \mathrm{~m}$ \\
Time zone & GMT-7 \\
Average temperature & 50 \\
Average wind speed & $2.4 \mathrm{~m} / \mathrm{s}$ \\
Direct normal (beam) & $6.35 \mathrm{kWh} / \mathrm{m}^{2} / \mathrm{day}$ \\
Diffuse horizontal & $1.41 \mathrm{kWh} / \mathrm{m}^{2} /$ day \\
Global horizontal & $5.01 \mathrm{kWh} / \mathrm{m}^{2} / \mathrm{day}$ \\
\hline
\end{tabular}

Table 1 provides details on the location of the project site.

\section{Meteorological Conditions}

Table 2 and Figures 2-4 provide the weather and solar conditions at the chosen site location.

\section{Solar Power Plants}

In this section of the paper, the various types of Solar Power Plants are discussed. Solar energy has been a replacement for fossil fuels in recent years for the generation of clean energy among other renewable energies and it is effective for both utility-scale and distribution scale power production. In 2019, 137.5 GW of solar power plant power was installed which is a 34.3 percent increment over 2018 [6]. In general, solar power generation is classified into two types: Photovoltaic (PV) and Concentrated Solar Power (CSP) system. A photovoltaic system can be used as both utility and larger-scale power generation based on the requirement. With the substantial decrease in the price and technological advancements, PV 
Table 2. Meteorological conditions for the project location.

\begin{tabular}{|c|c|}
\hline Weather Condition & $\begin{array}{l}\text { Excessively hot during summer and very cold, dry during winter. } \\
\text { Denver receives } 245 \text { days of sunshine on average per year. }\end{array}$ \\
\hline Climatological Data & $\begin{array}{l}\text { Highest Temperature-89 F (July) } \\
\text { Average Temperature-50.15 F } \\
\text { Lowest Temperature-19.4 F (December) }\end{array}$ \\
\hline Humidity & The average relative humidity is $52 \%$ \\
\hline Annual Rainfall & $\begin{array}{c}\text { Average Denver receives } 17 \text { inches of rain per year } \\
\text { Maximum }-1.9 \text { inches (May) } \\
\text { Minimum }-0.1 \text { inches (December) }\end{array}$ \\
\hline Snowfall & $\begin{array}{c}\text { Denver's averages snowfall is } 60 \text { inches per year } \\
\text { Maximum }-11 \text { (March) } \\
\text { Minimum }-1 \text { inch (May \& September) }\end{array}$ \\
\hline Wind Direction & $\begin{array}{l}\text { Maximum Wind Speed-10.0 m/s } \\
\text { Average Wind Speed-2.4 m/s } \\
\text { Minimum Wind Speed-6.6 m/s }\end{array}$ \\
\hline
\end{tabular}

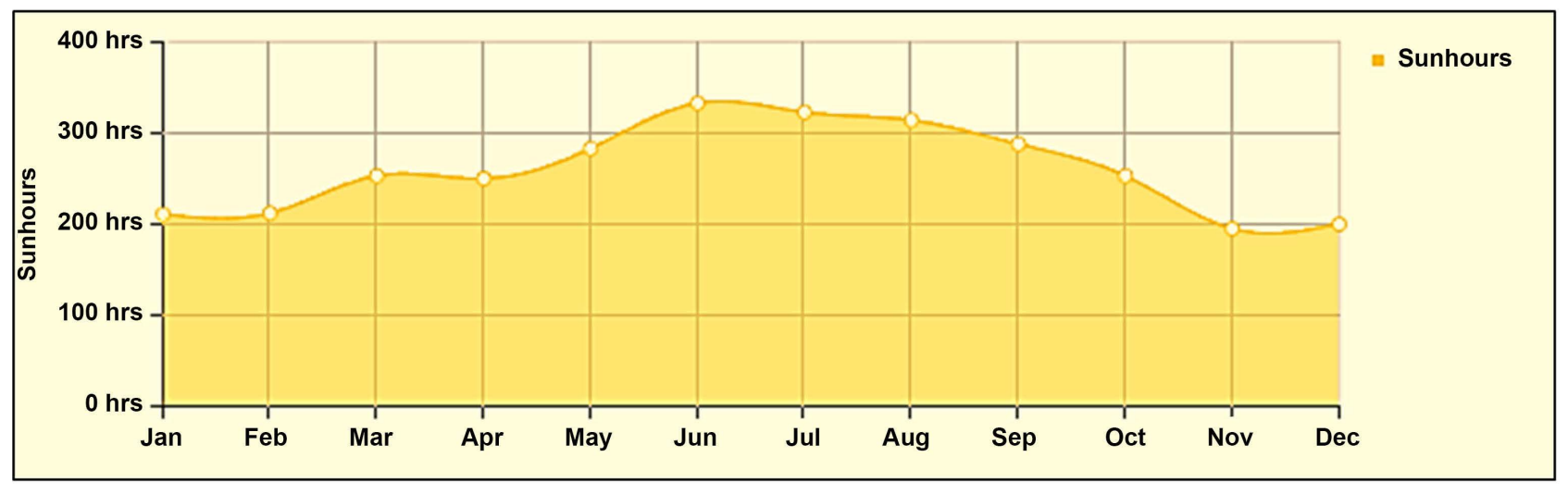

Figure 2. Monthly sun hours.

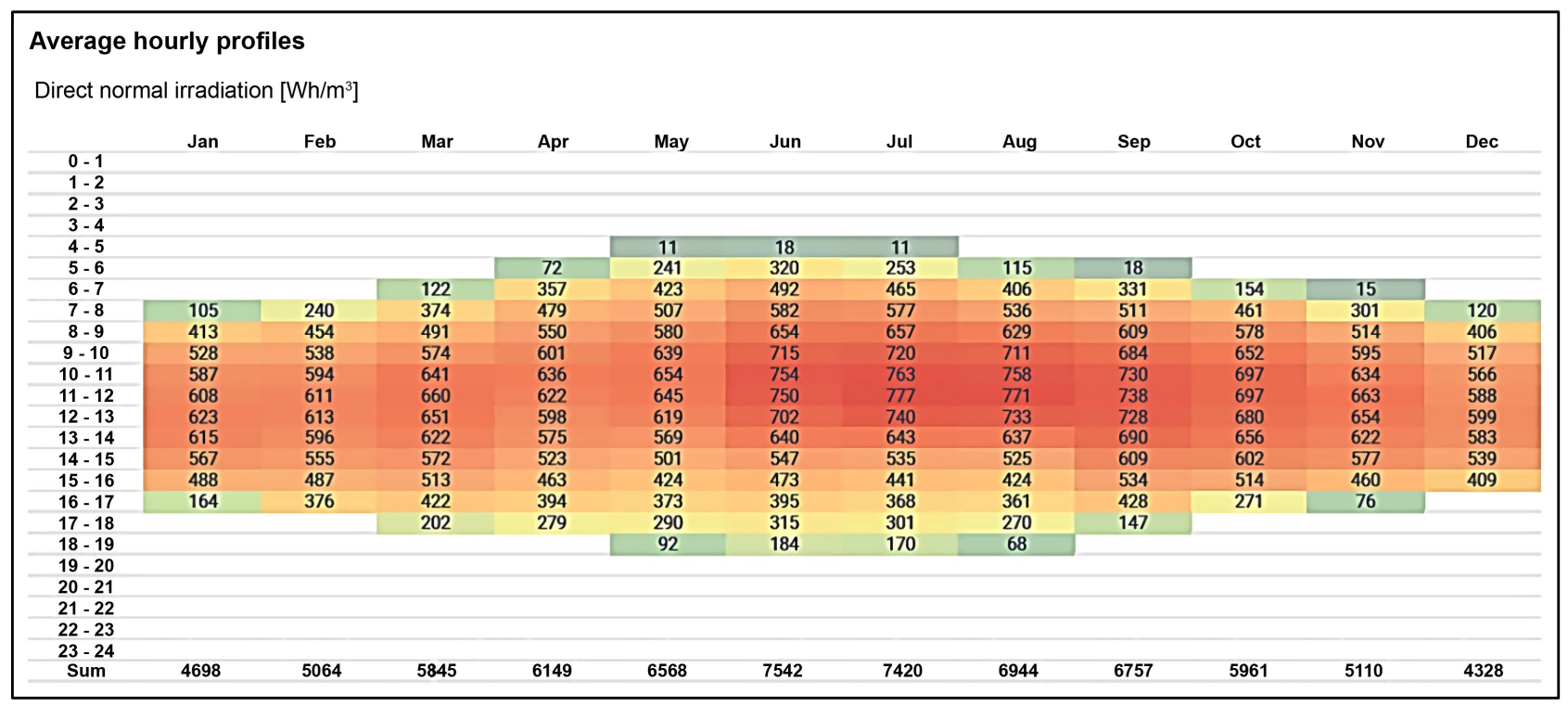

Figure 3. Average hourly profile DNI. 


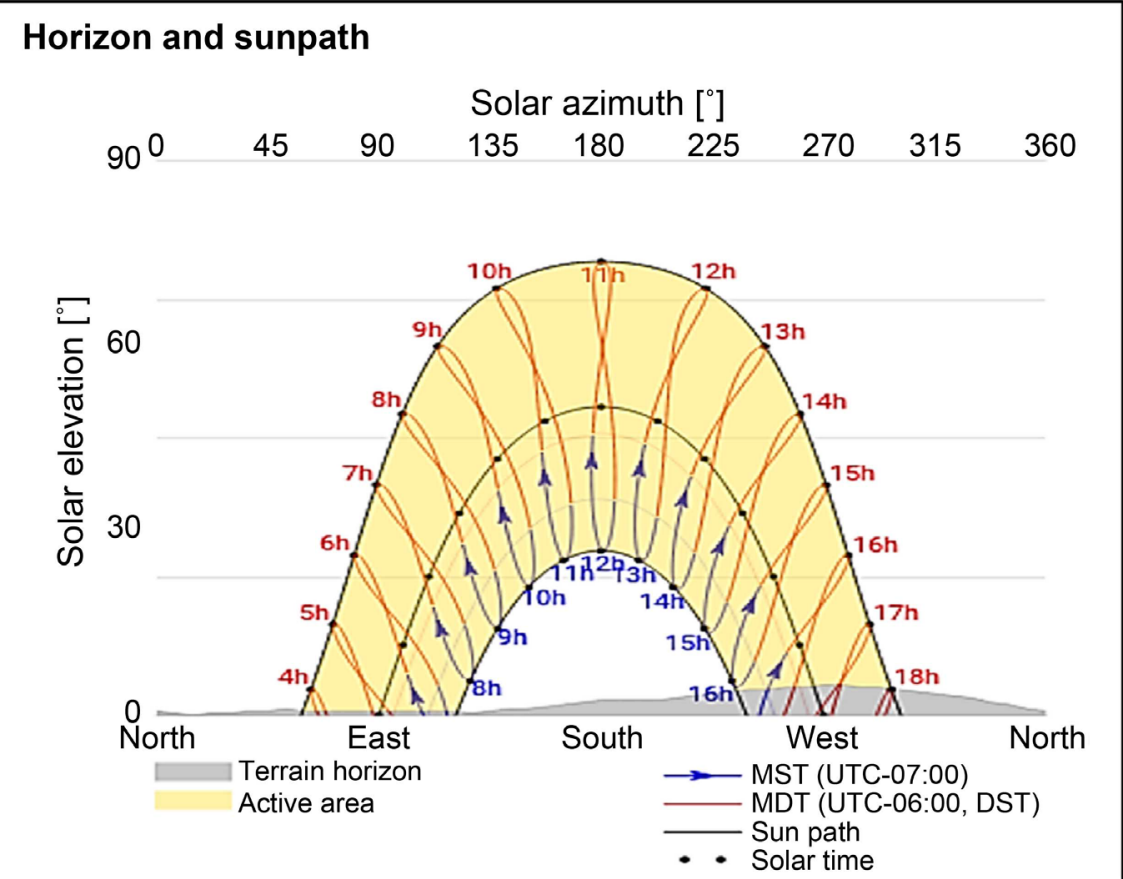

Figure 4. Solar azimuth angle.

panels were made more sustainable and with the improvement in efficiency, their use for electricity generation has increased. The power output from PV panels is in direct current (DC) mode and by using an inverter it is converted to alternating current $(\mathrm{AC})$ before distribution. Whereas concentrated solar power is based on the Rankine cycle where the solar radiation hits the surfaces of concentrated lens or mirror in large quantity which directs the sunlight to a receiver that heats the fluid. Then it can be used to generate electricity using a steam turbine and the hot fluid can be stored in a tank for power generation during the nighttime or for peak demand. Installing a CSP power station is more expensive than any other renewable energy power source. The price might vary based on how long hot fluid is stored in the tank. This paper discusses the implementation of ground-mounted PV panels, the Concentrated Solar Power Tower System, and the Linear Fresnel Reflector System.

\subsection{Photovoltaic Power Plant}

The photovoltaic power plants can be classified into two types: fixed or tracking. For the fixed PV system, the tilt and azimuth angle of the module is fixed or unaltered whereas the tracking PV system maintains the solar radiation perpendicular to the surface of the module. Single-axis and dual-axis tracking systems are the most common types used for the tracking PV system. The fixed system is cheaper than the tracking PV system and requires less maintenance. For this project a grounded-mounted fixed PV system was adopted.

The PV system doesn't require any moving parts, has considerably low noise and zero air pollution. The energy production from PV panels is directly related 
to the efficiency and, in general, the highest efficiency of commercial PV panels is approximately 23 percent. PV cells, with well-doped silicon, will generally produce the most energy.

A PV system consists of modules, an inverter, a mounting system, a monitoring system, a disconnect switch, transformers, and batteries. The mounting system helps the PV panels to withstand any weather conditions. PV modules produce DC current and the inverter converts the DC into AC with the desired voltage before supplying it to the grid. The inverter is connected to the active grid because it should be working 24/7. The disconnect switch is used to avoid any system failures. The transformer is used to regulate the voltage depending on the voltage route either to step up the voltage or step down the voltage and it acts as the incoming and outgoing voltage route for keeping the inverter active. It can also draw power from the transmission line. Batteries are not required if the power is provided uninterrupted to the grid. In general, a PV system has 25 years of manufactured warranty [7] and with an expected life expectancy of 20 30 years. PV panels are the major investments in a PV power plant and for this project, one-third of investment price goes to PV modules.

\subsection{Concentrated Solar Power (CSP)}

The working principle of a traditional concentrated solar power plant is by using the mirror to direct the solar radiation to a receiver, which heats the heat transfer fluid (HTF) that is used to run a turbine to generate electricity. A CSP system is expensive compared to another renewable energy system [8]. In contrast, the capacity factor of the CSP system is much higher than other renewable energy resources. Installation costs of a CSP are primarily based on the storage system and with a longer storage capability, the price will be higher. With the help of a storage system, the CSP system can produce energy directly or meet the energy requirement during nighttime or peak hours. A CSP system generates a comparatively low amount of greenhouse gases compared to any fossil fuel power plant. The most common CSP systems are the parabolic trough, the CSP tower, the Dish Engine, and the Linear Fresnel Reflector system.

The CSP parabolic trough system consists of a curved mirror that concentrates the sunlight radiation to a receiver tube which contains heat transfer fluid (HTF) like water or molten salt as shown in Figure 5. By concentrating the solar radiation on the receiver, the radiation heats the HTF and the HTF is passed on to a heat exchanger to produce steam which helps run a steam turbine to generate electricity. Each parabolic trough has separate receiver tubes. For a Linear Fresnel Reflector system the working principle is the same as for the parabolic trough, but the Fresnel system has a linear flat mirror. The Dish engine operates with parabolic reflectors that concentrate the solar radiation to a focal point on a receiver which contains a small-scale turbine or Stirling engine that generates electricity.

A concentrated solar power tower working principle is the same are the parabolic trough, by concentrating the radiation to the receiver which contains 


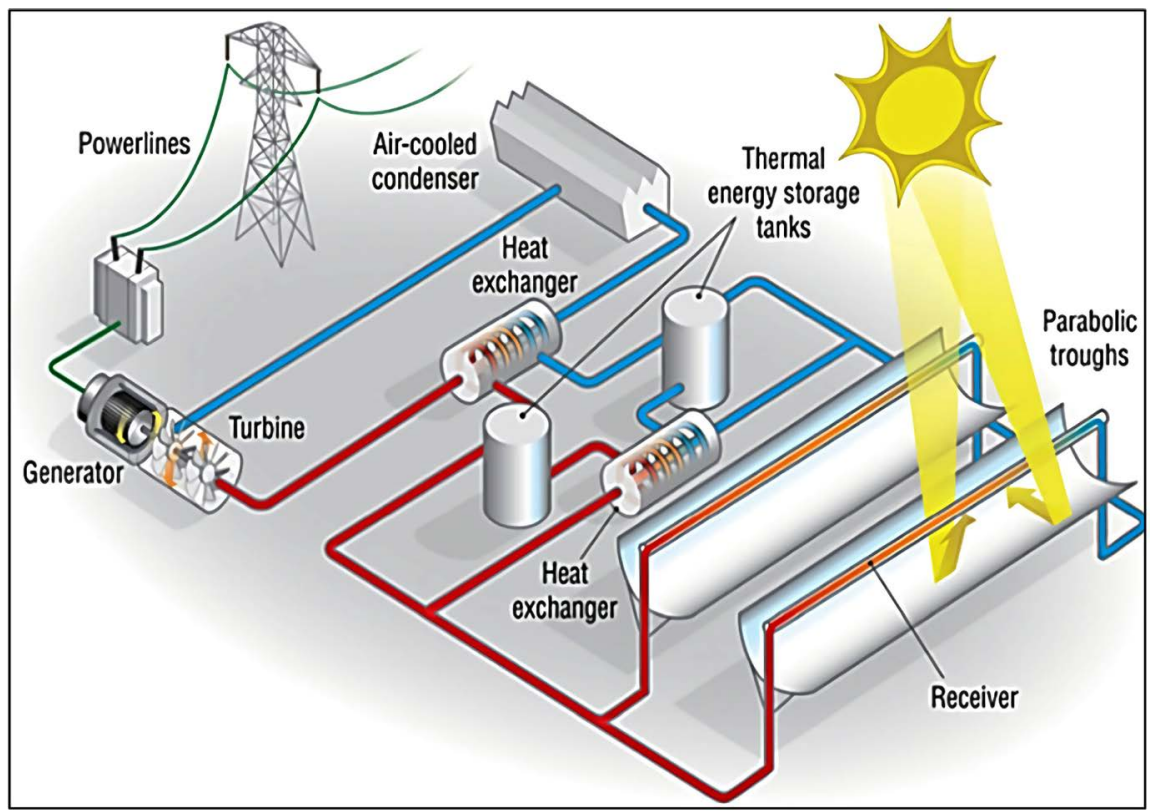

Figure 5. CSP figure parabolic trough.

HTF and the high-temperature HTF is passed to a Heat exchanger to produce steam. The main difference is that CSP tower system has a common receiver with a field of mirrors that are positioned to direct the radiation towards the single receiver shown in Figure 6. Unlike other solar systems, the CSP tower system is not efficient for small-scale energy production.

\subsection{Concentrated Solar Power (Power Tower)}

In this paper concentrated solar power tower is considered one of the power plants. As shown in Figure 6, the CSP tower system consists of field mirrors know as heliostats, a tower with a receiver, heat transfer fluid, storage tank, heat exchanger, and a steam turbine. The tower system uses heliostats that track the solar radiation and concentrates it on a single receiver at top of the tower. Solar radiation is concentrated $800-1000$ times on the receiver to achieve working fluid temperature of $500^{\circ} \mathrm{C}-800^{\circ} \mathrm{C}$. The receiver contains a heat transfer fluid which gets heated up and it passes through the heat exchanger to generate steam with a temperature from $450^{\circ} \mathrm{C}-750^{\circ} \mathrm{C}$. The steam turbine then generates electricity with the superheated steam. A storage system is used to store and maintain the temperature of HTF for 6 - 10 hours for nighttime operation and for use during peak loads. The largest CSP tower plant in the USA, located in California's Mojave Desert, is a 392 MW plant and consists of 173,500 heliostats which can provide electricity to approximately 100,000 homes [9].

\subsection{Wind Turbine}

Wind energy is a growing source of energy supply and is an available renewable energy source in Colorado. As of 2019, Colorado's installed capacity of the wind turbines is around $3762 \mathrm{MW}$ and an additional $500 \mathrm{MW}$ is under construction. 


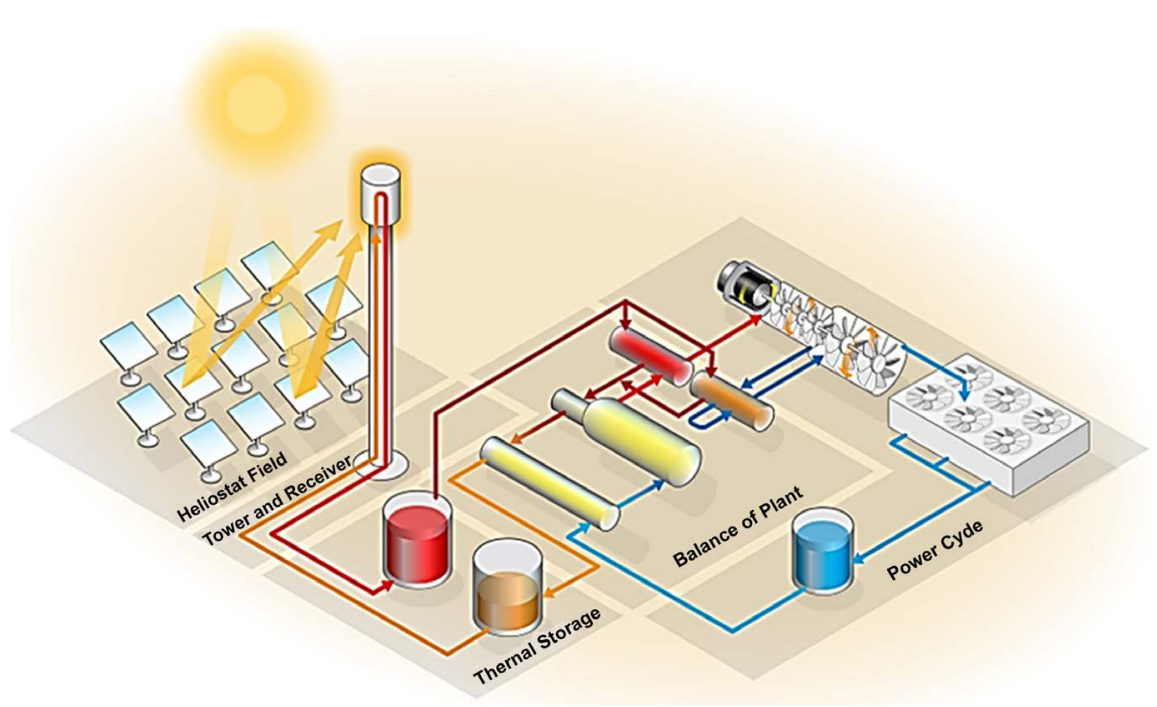

Figure 6. Concentrated solar power tower.

From 2005 to 2019, the power produced by wind energy to the grid increased by $14.07 \%$. 10,925 MWh of electricity was supplied to the grid [10]. Colorado has one of the largest wind farms in the United States. The Limon Wind Energy Center has a capacity of $601 \mathrm{MW}$ [11]. According to the Energy Information Administration, in 2016, Colorado was the country's seventh-largest wind producing state with more than $4 \%$ of wind production in the country. Wind energy accounts for the largest percentage of renewable energy generation in Colorado, with more than $19.44 \%$ of cumulative electricity generated in 2019. Figure 7 shows a map of the wind resources available in Colorado [12].

\section{Combined Cycle Power Plants}

In this section of the paper, the various combined cycle power plants are discussed. The main use of a power plant, as shown in Figure 8, is to meet the requirements of electricity demand and the need to achieve a high level of performance and operational capability. For a combined cycle power plant, the number of turbines required is based on the plant requirement by weighing the baseload point at which they operate. A combined-cycle power plant can meet the load requirements by operating under both baseload and peak load demand. Besides operating hours per year, the operating conditions based grid demand need to be considered during the design process. Financing plays a major role in building any power plant. All power plants in the market are evaluated in terms of $\$$ /MWh during the financial evaluation process. Levelized cost of electricity determines how efficiently the power plant operates. For a combined cycle power plant the initial capital cost, fixed operation and maintenance cost (O\&M), variable O\&M cost, and fuel prices are considered. For the combined cycle, the inlet temperature, pressure and steam flow rate should be considered in the design process, along with the fluctuation of the various working conditions and load demand. The temperature, pressure, and additional flow rate of the condensed 


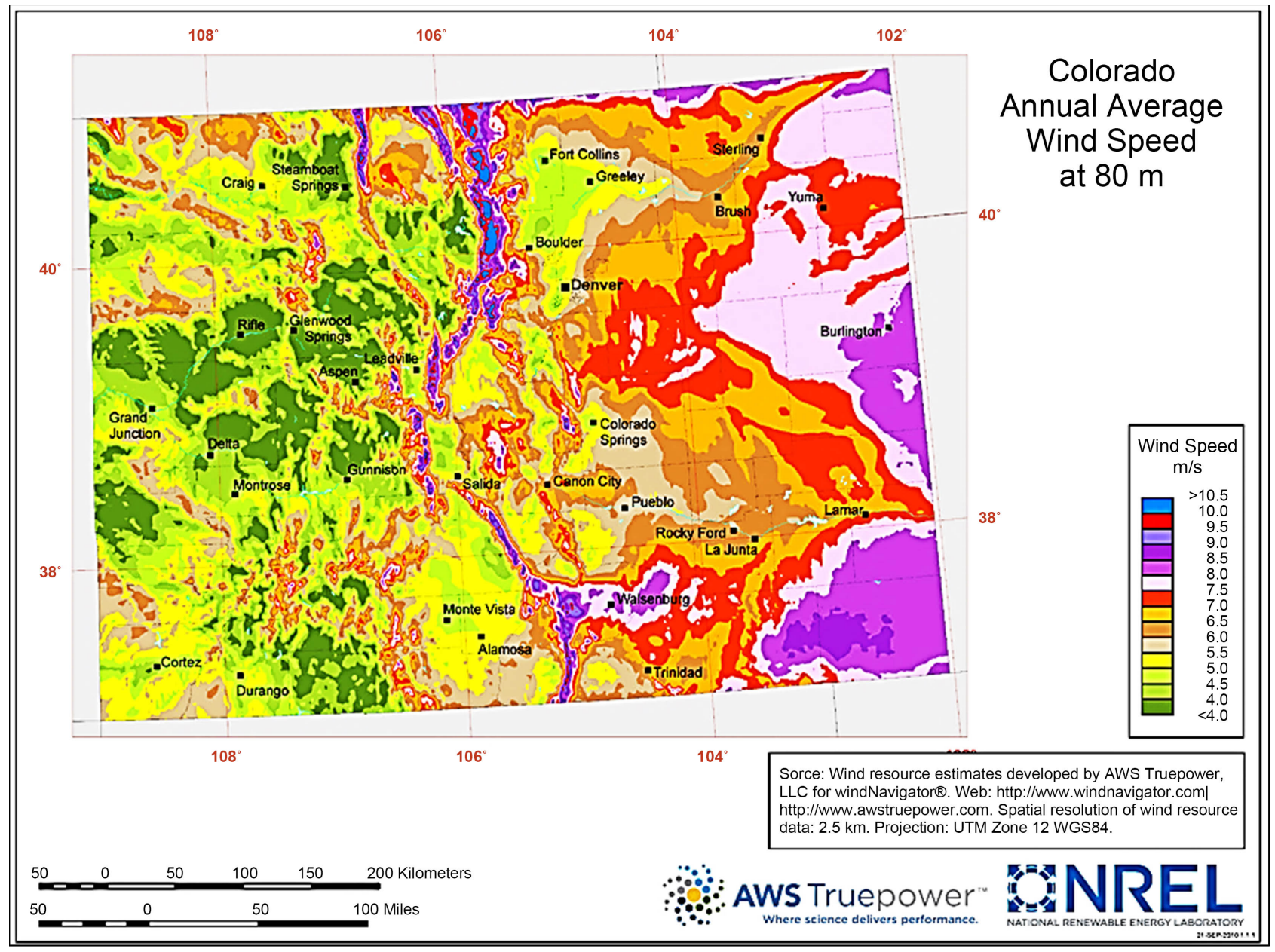

Figure 7. Colorado wind resources.

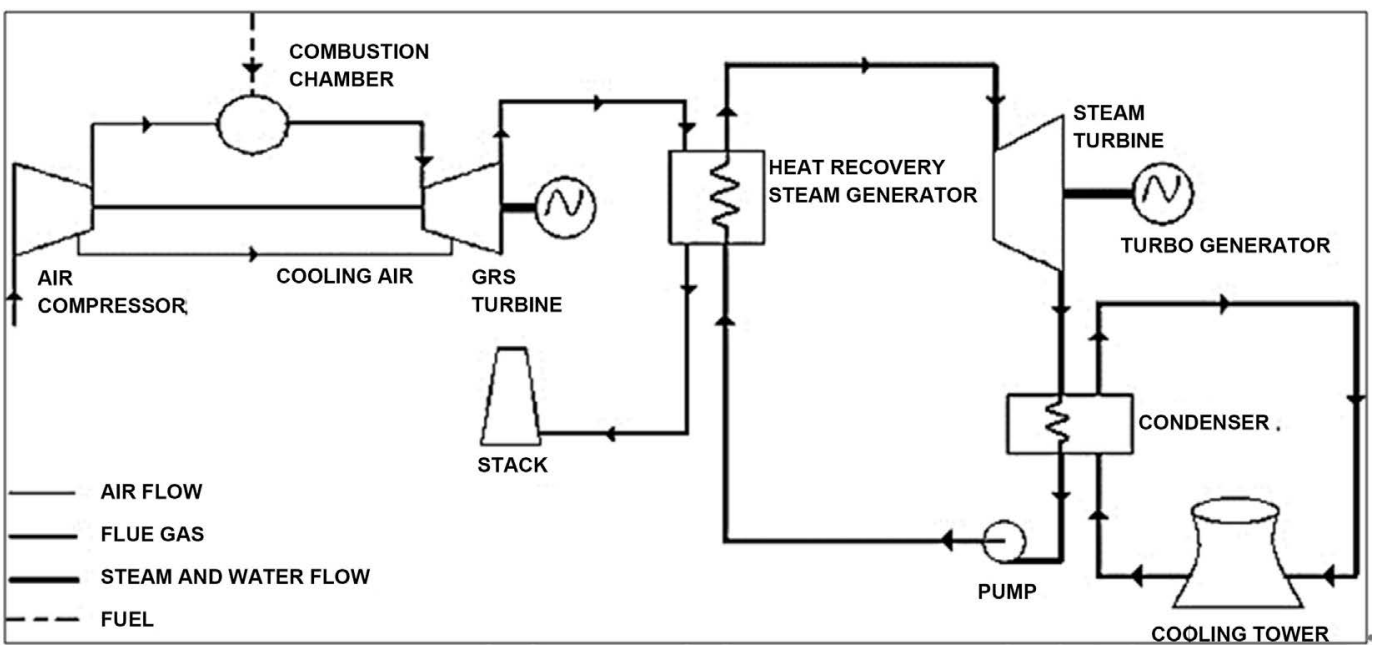

Figure 8. Combined cycle power plant.

steam required to meet the load should also be considered during the design stage. Site-related factors make a huge impact on operating condition, especially for the regional electricity grid whether it is rated at 50 or $60 \mathrm{~Hz}$. Larger turbines 
are designed for specific frequencies, whereas small turbines can run under any specific frequencies since they are usually operated with gear drives.

\subsection{Natural Gas Combined Cycle (NGCC) Power Plant}

In a Combined Cycle Combined Cycle power plant as shown in Figure 9, the gas turbine generates electricity and the waste heat from the gas turbine is used to generate superheated steam which runs the steam turbine to generate additional power. The working principle of the combined cycle is based on two thermodynamic cycles known as the Brayton cycle and the Rankine cycle. In an NGCC, the beginning process is the Bryton cycle which is also called a topping cycle. A topping cycle consists of a compressor, combustor, and a gas turbine. In an open circuit gas turbine operation, atmospheric air is compressed and purified using a compressor, the compressed air is passed to a combustor where the compressed air is mixed with the fuel and ignited which increases the turbine inlet temperature (TIT) and causes the air to expand into the turbine. The high pressure from the expansion drives the gas turbine which generates electricity using a generator connected by a shaft. The second process in an NGCC is the Rankine cycle also considered as a bottoming cycle. The bottoming cycle starts with the Heat recovery steam generator (HRSG) driven by the waste heat from gas turbine causes the HRSG to generate steam. The generated steam drives the steam turbine to generate supplementary electricity. Then the steam is condensed, using a condenser, and pumped back to the HRSG.

Ambient conditions place a significant role in the operational efficiency of a combined cycle. Manufacturers design a gas turbine to operate at the ISO ambient conditions of $15 \mathrm{C}, 1.013$ bar and 60 percent relative humidity [13]. The gas turbine performs differently under different ambient conditions which affect

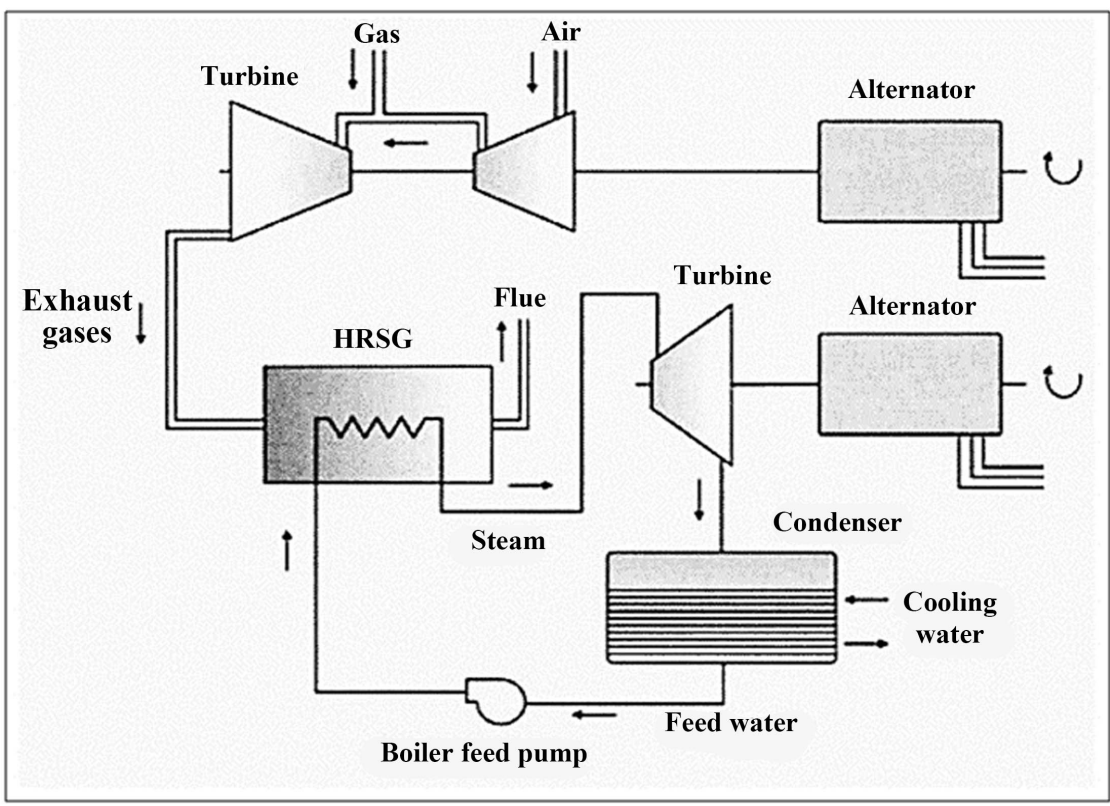

Figure 9. Simple natural gas combined cycle power plant. 
the steam cycle. The gas turbine output depends on the ambient air temperature. With a rise in ambient temperature, the density of the air is decreased which reduces the mass flow rate of air and reduces the gas flow rate of the turbine. Even if the turbine inlet temperature remains constant, the rise in ambient temperature decreases the efficiency of the gas turbine. Ambient pressure and relative humidity affect the operation of a combined cycle, but not as much as ambient temperature.

Fuel composition influences the performance and produced emissions and determines the power output of the overall combined cycle system. It determines the enthalpy change in gas turbine and the resulting steam temperature and pressure in the heat recovery steam generator. An important factor that needs to be considered for the fuel is the lower heating value (LFV). A low LHV results in a higher mass flow rate of fuel. Hence, for higher power output and efficiency, low British thermal unit (BTU) gases should be supplied at the required pressure for efficient operation of the gas turbine.

\subsection{Integrated Solar Combined Cycle (ISCC)}

The integrated solar combined cycle is a combination of the concentrated solar power and natural gas combined cycle power plants as shown in Figure 10. In the operation of an ISCC power plant, the fossil-fuel consumption is reduced which results in a reduction of greenhouse gas emissions. By integrating the NGCC power plant with a CSP power plant, the overall cost of the power plant will decrease. In general, CSP power plants have a high initial cost. The LCOE and O\&M costs will be reduced by combining both the power plants [14]. Power output from the Rankine cycle power plant will increase in the NGCC power

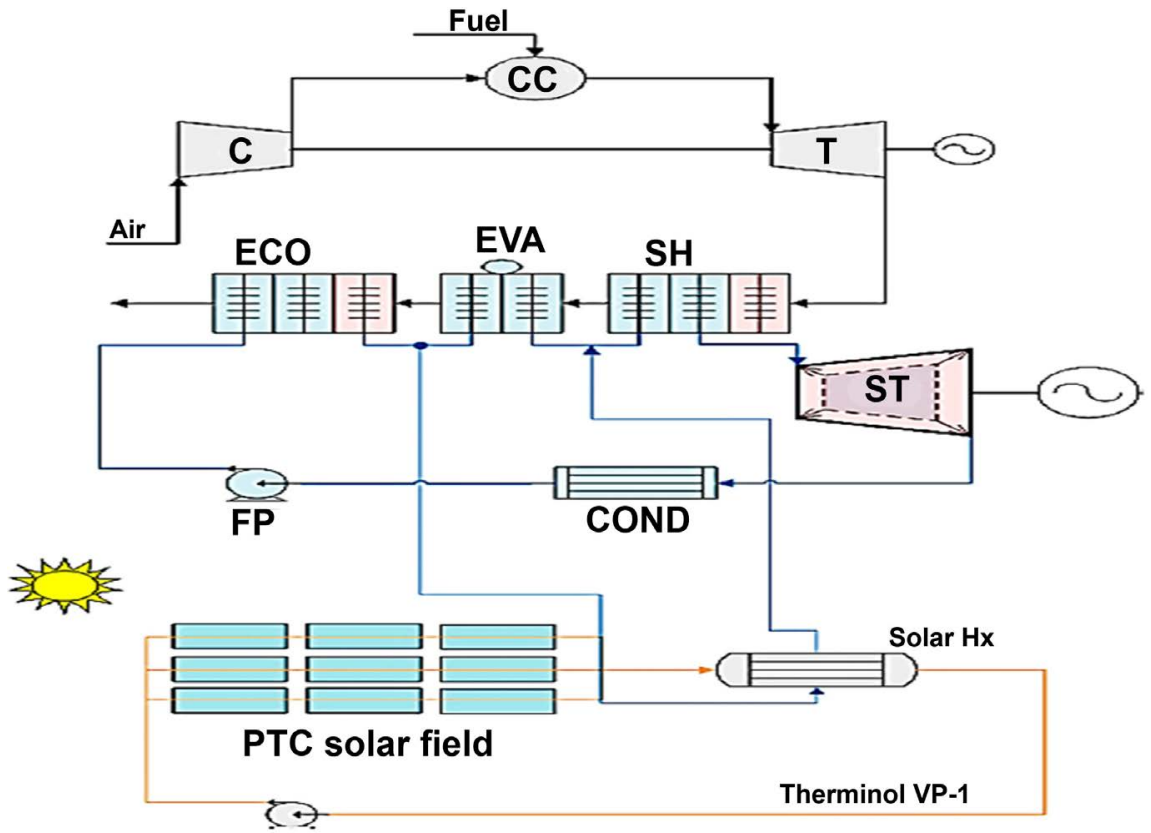

Figure 10. Layout of simple cycle ISCC power plant. 
cycle as additional steam is supplied by the solar cycle. The thermal storage system for the solar thermal system can be reduced significantly or eliminated because NGCC can provide a leveling effect when there is a variation in irradiation.

The efficiency of the ISCC power plant can be increased based on a few methods. The first method is the solar-gas turbine hybridization. Before supplying the compressed air into the combustion chamber, the compressed air from the compressor is pre-heated. Increasing the inlet temperature to the combustion chamber results in an increase in turbine inlet temperature, which causes an increase in the enthalpy change in the gas turbine and results in an increase in the output of the turbine. Eventually, the exhaust temperature of the gas turbine will be high and a high exhaust temperature increases the bottoming-cycle Rankine cycle efficiency. Hence, the overall ISCC efficiency is increased. In the second method, steam generated by the solar cycle and NGCC cycle is mixed in the HRSG section. By increasing the steam flow rate and steam temperature, the overall Rankine cycle output is increased. However, this method doesn't affect the gas turbine efficiency [15]. In this paper, the ISCC model has been analyzed thermodynamically by implementing the solar thermal system in the NGCC by considering the variation in ambient conditions and the steam input from the solar thermal cycle.

\section{Evaluation of the Solar Power Systems}

\subsection{PV Simulation}

The ground-mounted PV system was chosen for this project and a fixed-tilt ground-mounted system was considered. The power plant was constructed in an unshaded region and the PV panels were assembled to optimize to maximize the energy generated. The PV panels were tilted at 35 degrees to obtain the maximum efficiency from the power plant. SunPower PV panels were chosen for this project, as they have a high efficiency, a high capacity factor and a good temperature coefficient [16]. The Sun power SPR-X22-370 PV panel was chosen for the proposed system for this project and Figure 11 displays added information about the panel.

The operation and maintenance cost for a PV power plant was less compared to any other power plant. The O\&M costs for a fixed tilt, ground mounted PV

\begin{tabular}{|ll|}
\hline Modules & \\
\hline SunPower SPR-X22-370 & \\
Cell material & Mono-c-Si \\
Module area & $1.63 \mathrm{~m}^{2}$ \\
Module capacity & $370.12 \mathrm{DC}$ Watts \\
Quantity & 27,016 \\
Total capacity & $10 \mathrm{DC} \mathrm{MW}$ \\
Total area & $44,036 \mathrm{~m}^{2}$ \\
\hline
\end{tabular}

Figure 11. Performance model. 
power plant was approximately 0.17 percent of the total installation. Water was the main source used for the cleaning process for the PV power plant and the water required for the PV system was less compared to the CSP system. For cleaning, dry air blowers or a robotic system can be used for the PV system to reduce water usage.

The proposed $10 \mathrm{MW}$ PV power plant was designed by inputting the required data into the National Renewable Energy Laboratory's System Advisor Model (SAM) The SAM program determines the Levelized cost of energy (LCOE), capacity factor, simple payback period, monthly energy generation for the power plant for a 25 year period. Figure 12 presents the simulation results resulting from the output from SAM.

\subsection{Concentrated Solar Power Tower}

For the concentrated solar power tower, the indirect system method was considered for this project. For heat transfer fluid (HTF), molten salt was selected. The salt absorbs heat from the receiver and generates steam in the heat exchanger [17]. By implementing the indirect system, the thermal efficiency was increased as it doesn't require fluid pressure as high as the direct system. For the given location the design point using the direct normal irradiance was considered to be $608 \mathrm{~W} / \mathrm{m}^{2}$. Using the SAM program, the heliostat field was analyzed and optimized. The SAM program calculates the number of heliostats and the layout by considering the tower dimensions. A total of 800 heliostats were deployed for this project. The designed temperature for heat transfer fluid leaving the receiver was $570^{\circ} \mathrm{C}$ and the receiver $\mathrm{HTF}$ inlet temperature was maintained at $353^{\circ} \mathrm{C}$. For the power cycle, the Rankine cycle was selected. The thermal energy from the HTF was transferred with a heat exchanger to generate steam

\begin{tabular}{|ll|}
\hline Metric & Value \\
\hline Annual energy (year 1) & $17,697,652 \mathrm{kWh}$ \\
Capacity factor (year 1) & $20.2 \%$ \\
Energy yield (year 1) & $1,770 \mathrm{kWh} / \mathrm{kW}$ \\
Performance ratio (year 1) & 0.81 \\
Levelized COE (nominal) & $2.63 \phi / \mathrm{kWh}$ \\
Levelized COE (real) & $2.10 \phi / \mathrm{kWh}$ \\
Electricity bill without system (year 1) & $\$ 135,571$ \\
Electricity bill with system(year 1) & $\$-471,022$ \\
Net savings with system (year 1) & $\$ 606,593$ \\
Net present value & $\$ 794,366$ \\
Simple payback period & 12.8 years \\
Discounted payback period & $\mathrm{NaN}$ \\
Net capital cost & $\$ 10,351,020$ \\
Equity & $\$ 4,140,408$ \\
Debt & $\$ 6,210,612$ \\
\hline
\end{tabular}

Figure 12. SAM result for PV system. 
for the Rankine cycle. The critical parameter in designing a CSP power plant was the storage system. For a given system, the hours for storing HTF at full load was 10 hours and the HTF temperature was varied from $348^{\circ} \mathrm{C}$ to a maximum of $574^{\circ} \mathrm{C}$. From the simulation, the efficiency of the power cycle was 43 percent. The operation and maintenance cost for the CSP was higher compared to the PV system. For the current project, the O\&M cost for CSP system was 6 times higher than for the PV system. Further, Figure 13 and Figure 14 show the results from the SAM simulation for the heliostat field and the operational parameters for the $10 \mathrm{MW}$ CSP power plant.

\subsection{Wind Power}

Vestas wind turbines were chosen for this project. The rated output of each turbine was $2 \mathrm{MW}$ with a rotor diameter of $100 \mathrm{~m}$, a hub height of $110 \mathrm{~m}$ and a shear coefficient of 0.14 . To get the maximum power out of wind turbines, large wind farms must be set up. For the current project 5 turbines were installed. The table in Figure 15 shows the SAM simulation of the Wind Turbine System. It shows the annual energy produced by analyzing the wind speeds throughout different times of the year, the capacity factor and the Levelized Cost of Electricity. From the data, it clearly shows that wind energy capacity factor is greater than photovoltaic panels and the CSP tower system.

\subsection{Natural Gas Combined Cycle (NGCC)}

The performance analysis of the Natural Gas Combined Cycle power plant was carried out using the Thermoflow software and the thermodynamic calculations were carried out using the Engineering Equation Solver (EES). For the initial analysis, the ambient condition for the power plant was determined based on the atmospheric conditions. Since the power plant was located in a high altitude

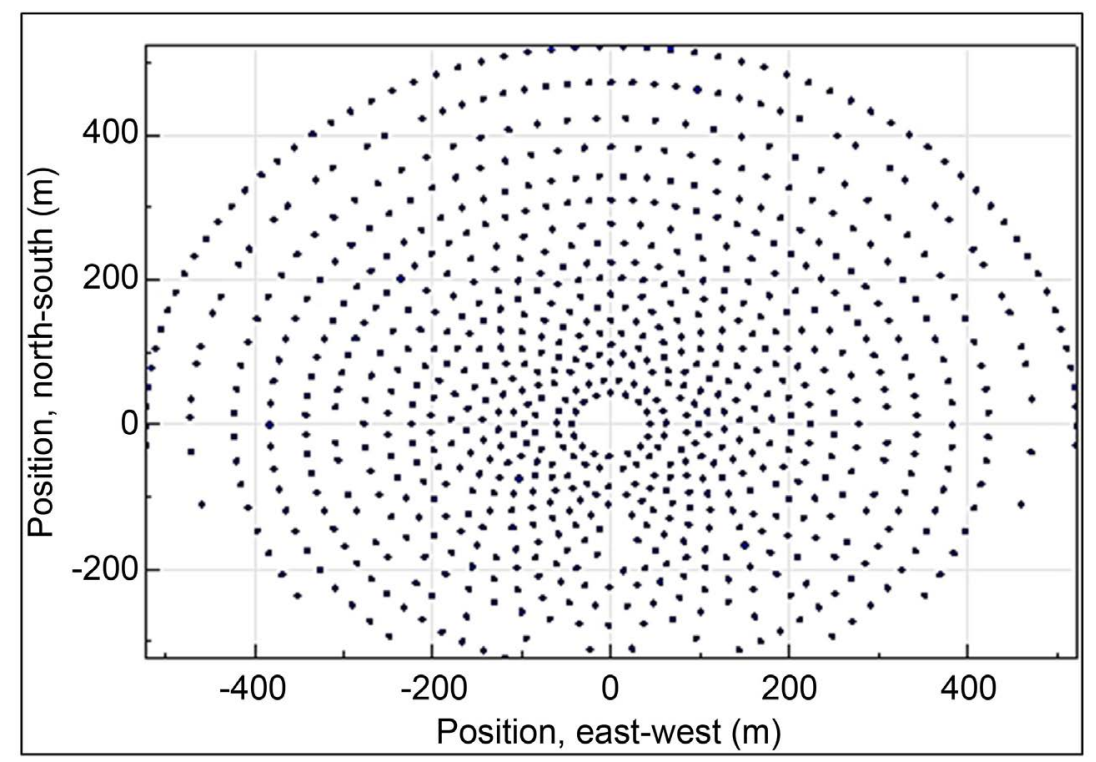

Figure 13. Heliostat field. 


\begin{tabular}{|ll|}
\hline Metric & Value \\
\hline Annual energy (year 1) & $38,036,716 \mathrm{kWh}$ \\
Capacity factor (year 1) & $43.9 \%$ \\
Annual Water Usage & $7,841 \mathrm{~m}^{3}$ \\
PPA price (year 1) & $15.80 \phi / \mathrm{kWh}$ \\
PPA price escalation & $1.00 \% / \mathrm{year}$ \\
Levelized PPA price (nominal) & $19.61 \phi / \mathrm{kWh}$ \\
Levelized PPA price (real) & $15.57 \phi / \mathrm{kWh}$ \\
Levelized COE (nominal) & $18.14 \phi / \mathrm{kWh}$ \\
Levelized COE (real) & $14.40 \phi / \mathrm{kWh}$ \\
Net present value & $\$ 5,466,135$ \\
Internal rate of return (IRR) & $11.00 \%$ \\
Year IRR is achieved & 20 \\
IRR at end of project & $12.76 \%$ \\
Net capital cost & $\$ 86,346,056$ \\
Equity & $\$ 40,125,796$ \\
Size of debt & $\$ 46,220,264$ \\
\hline
\end{tabular}

Figure 14. SAM result for concentrated solar power tower system.

\begin{tabular}{|ll|}
\hline Metric & Value \\
\hline Annual energy (year 1) & $40,100,984 \mathrm{kWh}$ \\
\hline Capacity factor (year 1) & $45.8 \%$ \\
\hline p90 Energy (year 1) & $33,897,740.0 \mathrm{kWh}$ \\
\hline Levelized COE (nominal) & $7.54 \phi / \mathrm{kWh}$ \\
\hline Levelized COE (real) & $5.98 \phi / \mathrm{kWh}$ \\
\hline Electricity bill without system (year 1) & $\$ 74,427$ \\
\hline Electricity bill with system (year 1) & $\$-3,543,540$ \\
\hline Net savings with system (year 1) & $\$ 3,617,966$ \\
\hline Net present value & $\$ 2,389,763$ \\
\hline Simple payback period & 13.5 years \\
\hline Discounted payback period & $\mathrm{NaN}$ \\
\hline Net capital cost & $\$ 74,000,000$ \\
\hline Equity & $\$ 14,800,000$ \\
\hline Debt & $\$ 59,200,000$ \\
\hline
\end{tabular}

Figure 15. SAM result for wind turbines.

$(1615 \mathrm{~m})$, the ambient condition varied from the ISO condition. For a gas turbine, a Siemens gas turbine model SGT-100 industrial gas turbine was considered. Figure 16 shows the layout of the NGCC Power Plant and Table 3 shows the performance data for a simple cycle [18].

As stated earlier, the inlet air temperature of a compressor can affect the efficiency of the gas turbine and the output of the gas turbine, hence, the output of the combined cycle was also affected [19]. The project site had a huge temperature variation throughout the year which caused a variation in the power output. By using the EES program, the power output and efficiency were calculated 
Table 3. Manufacturer's performance data for a simple cycle.

\begin{tabular}{cc}
\hline Power output & $5.05 \mathrm{MW}$ \\
Fuel type & Natural gas, liquid fuel, duel fuel \\
Frequency & $50 / 60 \mathrm{~Hz}$ \\
Gross efficiency & $30.2 \%$ \\
Heat rate & $11,914 \mathrm{KJ} / \mathrm{kWh}$ \\
Turbine speed & $17,384 \mathrm{rpm}$ \\
Pressure ratio & $14.0: 1$ \\
Exhaust temperature & $545^{\circ} \mathrm{C}$ \\
\hline
\end{tabular}

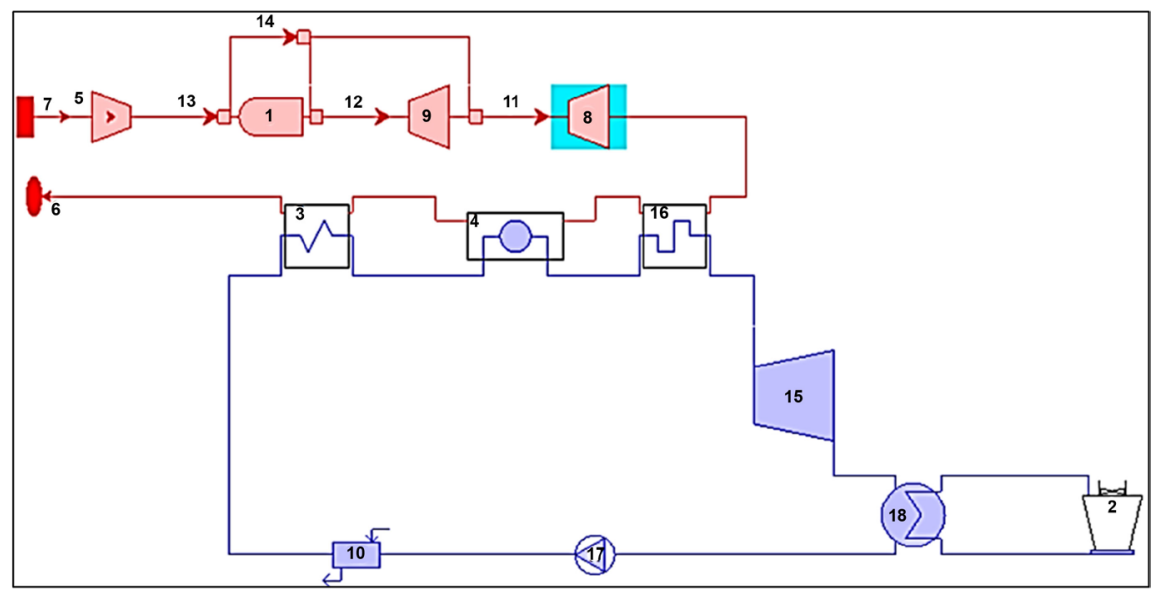

Figure 16. Layout of simple cycle NGCC power plant.

accounting for these temperature fluctuations. With the help of the Thermoflow software, a simulation for HRSG was done and the pressure values for the Rankine cycle were assumed to obtain the desired result. Figure 17 and Figure 18 show the gas turbine output, efficiency, and net output of the combined cycle.

The initial cost of a $10 \mathrm{MW}$ combined cycle power plant is $\$ 10,820,000$ which is less than the wind turbines, but the operation and maintenance cost of the natural gas combined cycle was high compared to PV and wind turbine power plants. The annual total cost of operating the ISCC was 53 times higher than the PV system.

\subsection{Integrated Solar Combined Cycle}

For the given Integrated Solar Combined Cycle project, the same NGCC gas turbine was considered and additional solar thermal energy was supplied by the Linear Fresnel reflector system [20]. A direct steam system was used for the ISCC. In the ISCC power plant, the working principle for the NGCC cycle (assumptions used in the ISCC Combined Cycle were the same as in the NGCC power plant) was the same but the additional solar thermal system supplied additional steam flow to the HRSG. Additional steam flow at high temperatures increased the Rankine cycle efficiency. When there was a decrease in thermal energy from 


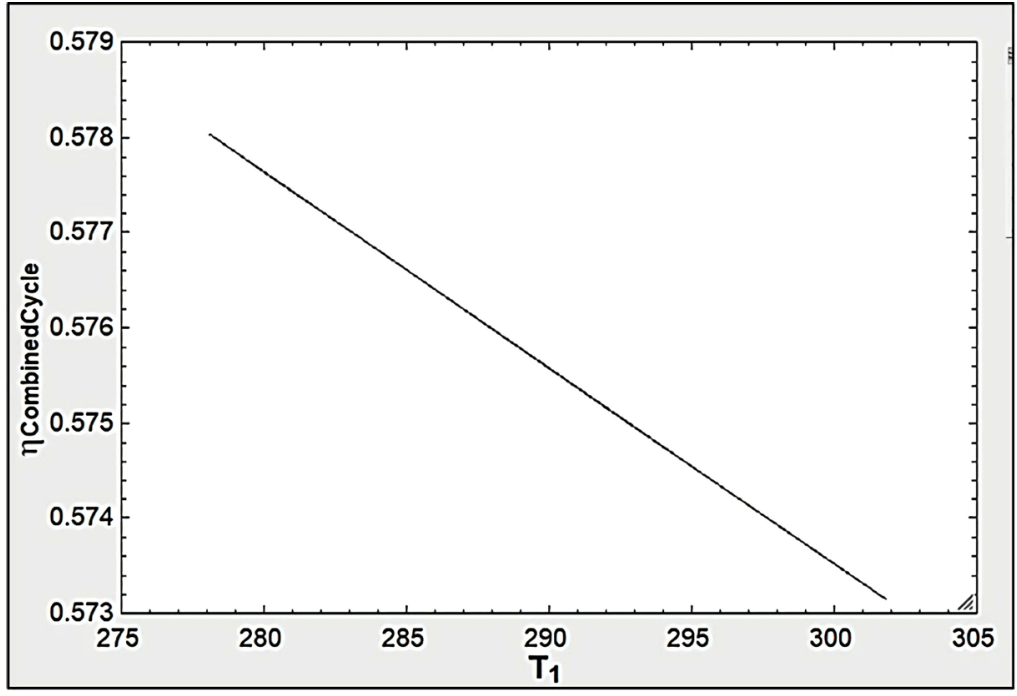

Figure 17. $T_{1}$ vs efficiency of combined cycle.

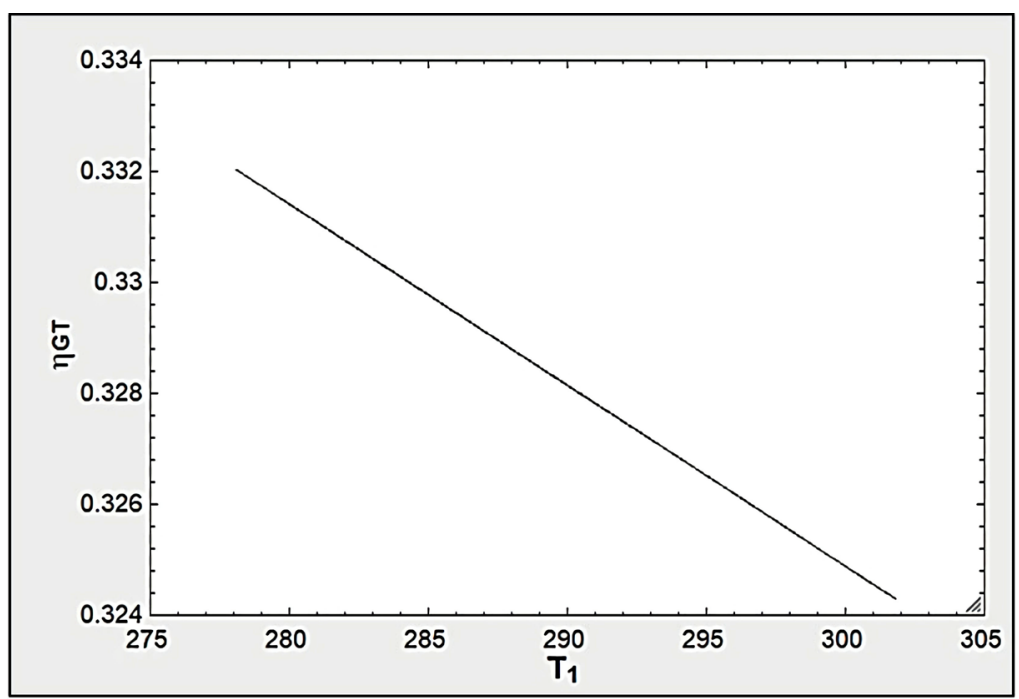

Figure 18. $T_{1}$ vs efficiency of gas turbine.

the solar cycle, to maintain the plant efficiency, the NGCC provided additional thermal energy to the Rankine cycle which provided damping to the thermal fluctuations. The thermodynamic calculation was done using the EES program for the ISCC. As a result of temperature variation during the year, the power output and efficiency were calculated accounting for these temperature fluctuations. With the variation in ambient temperature, the gas turbine power net output and efficiency of the ISCC are shown in Figure 19 and Figure 20.

The estimated initial capital cost for $10 \mathrm{MW}$ ISCC was $\$ 17,340,562$. Whereas the capital cost for the CSP power plant was approximately 4.5 times higher than for the ISCC. The results show that integrating the CSP system with NGCC made a large impact on the reduction in capital cost, O\&M cost and the Levelized cost of electricity (LCOE). Table 4 below shows the financial data for the Integrated Solar Combined Cycle. 
Table 4. Power plant comparison.

\begin{tabular}{cccccc}
\hline Power plant & PV system & CSP tower & Wind turbine & NGCC & ISCC \\
\hline Annual energy production & $17,697,652 \mathrm{kWh}$ & $38,036,716 \mathrm{kWh}$ & $40,100,984 \mathrm{kWh}$ & $63,571,565 \mathrm{kWh}$ & $64,943,646 \mathrm{kWh}$ \\
Net capital cost & $\$ 10,351,020$ & $\$ 86,346,059$ & $\$ 74,000,00$ & $\$ 10,830,000$ & $\$ 17,340,562$ \\
Capacity factor & $20.2 \%$ & $43.9 \%$ & $45.8 \%$ & $72.75 \%$ & $74.31 \%$ \\
LCOE & 2.63 cents/kWh & 19.6 cents $/ \mathrm{kWh}$ & 5.98 cents $/ \mathrm{kWh}$ & $9.91 \mathrm{cents} / \mathrm{kWh}$ & $18.9 \mathrm{cents} / \mathrm{kWh}$ \\
Annual O\&M cost & $\$ 122,956$ & $\$ 1,074,642$ & $\$ 505,354$ & $\$ 4,420,152$ & $\$ 4,835,160$ \\
Land requirement & 36.3 acres & 241 acres & 15 acres & 3.43 acres & 13.5 acers \\
\hline
\end{tabular}

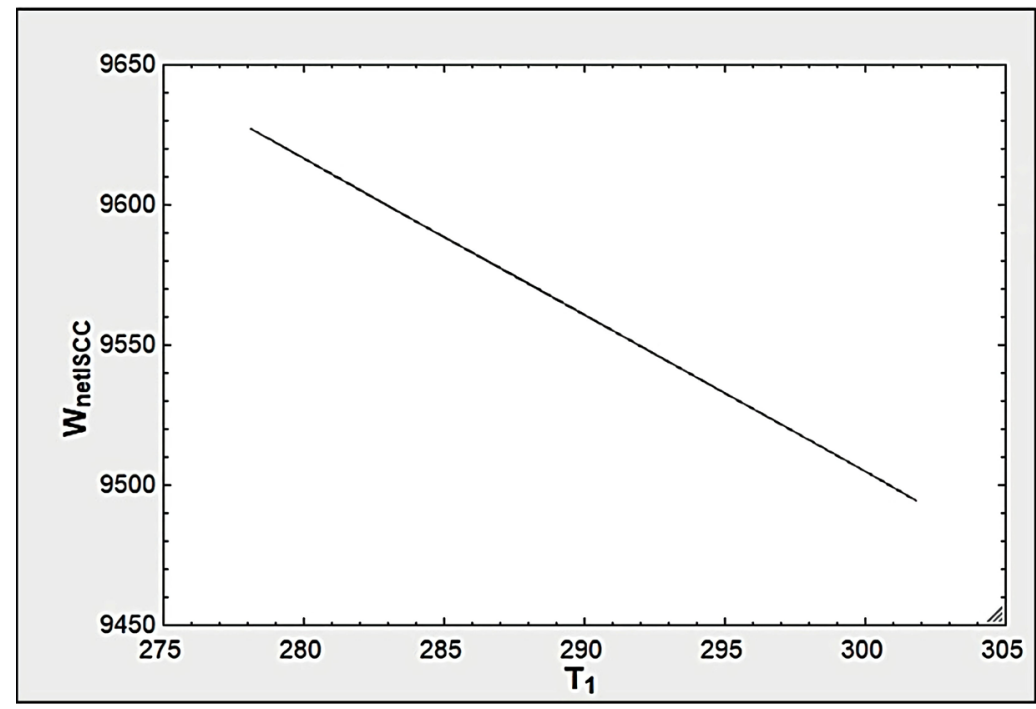

Figure 19. $T_{1}$ vs net output of ISCC.

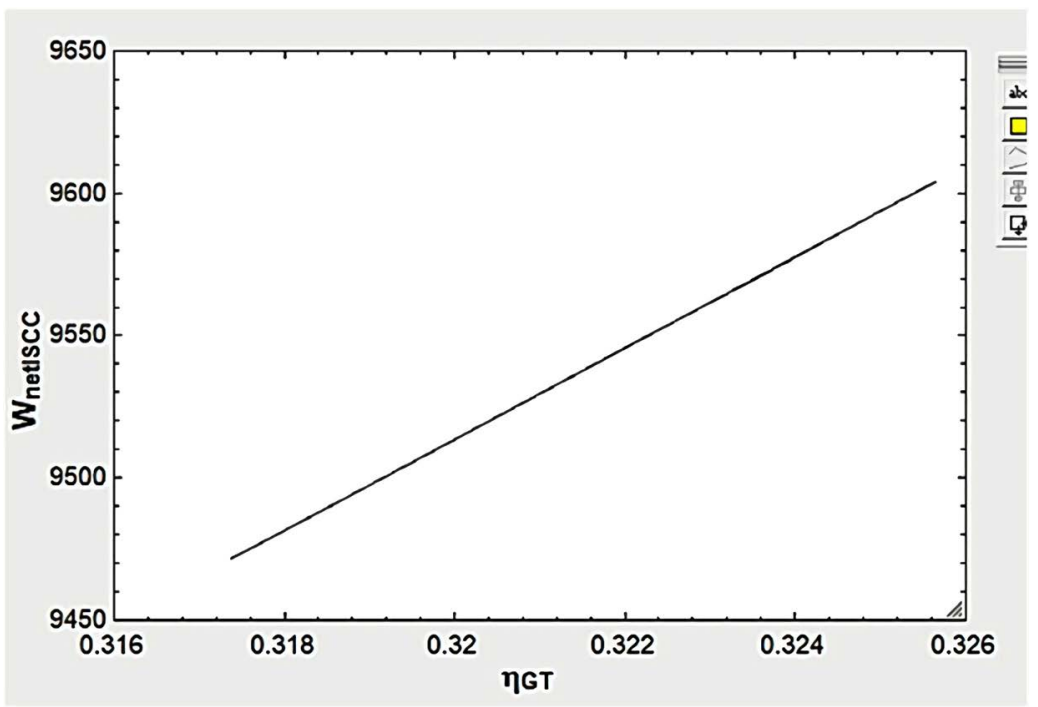

Figure 20. Network output of ISCC efficiency of gas turbine.

\section{Discussion}

The individual and combined power plant study of wind energy, solar energy, 
and natural gas was described earlier. This section describes the advantages of each power plant and compares them with the calculated data. Table 4 shows the comparison of the operation of the five different power plants.

- Installing solar photovoltaic panels was a good option because of its green energy with low emissions. On average Adams county received 245 days of sunshine which provided an excellent source of energy for the different power systems. With regard to the financial parameters, the PV system showed a huge improvement over the other systems. The LCOE and the payback period were good when compared to the wind energy system. Since the efficiencies of PV panels are improving, the best option for this power plant would be the Solar PV panels. Also, since the O\&M cost for a PV system is low and it has a 25 year warranty. For the long run the PV system would be a better solution.

- Wind energy is good for a long-term investment since the capacity factor was greater than for solar. Compared to the PV system, the initial cost and LCOE of the wind power plant were high.

- The energy production from the Concentrated Solar Power Tower system was large as it generates twice the amount of energy produced by the PV system. The capacity factor for the CSPT power system was also high. But the initial cost and LCOE for this power plant was high compared to any of the other power plants considered in this project.

- Overall, implementing the natural gas was more effective when it came to a short-term return on investment. The Levelized Cost of electricity was low compared to the Solar Thermal Power System. Also, the capacity factor of the natural gas power plant was high [21]. The operating cost of the natural gas power plant was high due to the price of natural gas. To control the greenhouse gas emissions of natural gas power plants, pollution control technology must be installed which adds to the operating cost.

- The ISCC power plant was a better replacement for the NGCC [22] and the CSP power plants [23]. Both power plants have their limitations and advantage, but by combining both the power plants the limitations can be lessened. For example, the LCOE value for CSP power plants was high, but by combining both these power plants the LCOE values were reduced. The overall efficiency of the ISCC system was high compared to NCGG and CSP systems.

\section{Conclusions}

Currently, renewable energy was a good replacement for fossil fuel energy. Recent operational data has proven that solar, hydro, and wind power are favorable replacements for fossil fuels. The cost of generating electricity from solar energy was very low compared to that of a coal or gas-fired power plant. A low-efficient solar power plant can overcome its drawbacks by providing clean energy generation, zero-emissions, and lower operation and maintenance costs. Even with the high initial cost, wind turbines can generate the same amount of energy as a 
gas-fired power plant. The operation and maintenance cost for a PV system and the wind turbine were low and both technologies can operate without any interruption for more than 25 years. The Concentrated Solar Power System has its limitations and advantages. Installing a CSP tower system, the DNI should be large for the power plant to generate enough energy to be profitable. The CSP system is not suitable for a location with a low DNI. The northeastern region of the USA is not suitable for the CSP system for large scale power production.

Even though the natural gas power plant generates more energy with less initial cost, the operating cost for the power plant was high. In the future, the O\&M cost of the natural gas power plant will increase as the gradual increase in fuel price will affect the $\$$ per MWh. To reduce air pollution (pollutants like SOx, NOx, and PM), the power plant must install better pollution control technology which leads to an increase in the cost of electricity generation per kWh. Meanwhile, solar energy and wind energy do not emit any pollutants. Additionally, the operation and maintenance costs of solar and wind were lower compared to those of a natural gas power plant. The LCOE trends for solar and wind power plants will decrease in the future as contrast to the LCOE trend for natural gas.

The ISCC system will be a good replacement for the natural gas combined cycle. The primary benefit of adopting to the ISCC power plant in the future is if the supply of natural gas is interrupted or the need to produce carbon-free energy, then it will be easy to shift the whole plant to operate on renewable energy sources either with biomass by making a small change with the current natural gas power plant or by converting the whole power plant to a CSP power plant.

In conclusion, the main aspect of the paper was to show the comparison and analysis of the thermodynamic characteristics and economic parameters for five distinct power plants. The results show that the wind power turbine has a stable energy production with a lower LCOE than the CSP, NGCC, or ISCC. By considering energy production, financial parameters, and the production of carbon-free energy, wind farms would be the best-suited power plant for this given project location with a capacity of $10 \mathrm{MW}$.

\section{Conflicts of Interest}

The authors declare no conflicts of interest regarding the publication of this paper.

\section{References}

[1] https://www.eia.gov/energyexplained/electricity/electricity-in-the-us-generation-ca pacity-and-sales.php

[2] https://www.volker-quaschning.de/datserv/CO2-spez/index_e.php

[3] https://www.euractiv.com/section/energy/opinion/mondaycop22-lower-co2-emissi ons-with-lower-carbon-solar-energy

[4] https://www.eia.gov/outlooks/aeo/pdf/electricity_generation.pdf

[5] https://www.forbes.com/sites/joshuarhodes/2020/02/03/the-us-solar-industry-in-20 
20/\#2d7b17d85ed3

[6] http://www.fi-powerweb.com/Renewable-Energy.html

[7] https://www.seia.org/state-solar-policy/colorado-solar

[8] https://www.communityenergyinc.com/projects/comanche-solar

[9] https://www.pv-tech.org/news/sunpowers-50mw-hooper-pv-plant-begins-commerc ial-operation-in-colorado

[10] https://www.energysage.com/solar-panels/solar-rebates-incentives/co

[11] https://www.nexteraenergyresources.com/pdf_redesign/limon.pdf

[12] https://windexchange.energy.gov/maps-data/15

[13] https://www.wartsila.com/energy/learn-more/technical-comparisons/combustion-e ngine-vs-gas-turbine-derating-due-to-ambient-temperature

[14] https://trepo.tuni.fi/bitstream/handle/123456789/26542/Pacios\%20Llorca.pdf?seque nce $=4$ \&isAllowed $=\mathrm{y}$

[15] Le-ol, A.K., et al. (2018) Comparative Assessment of Thermal Power Systems Performance under Uncertainty. European Journal of Engineering Research and Science, 3, 52-57. https://doi.org/10.24018/ejers.2018.3.7.710

[16] Kehlhofer, R. (1999) Combined-Cycle Gas \& Steam Turbine Power Plants. PennWell Publishing Co., Tulsa, OK.

[17] Zhu, G.D., et al. (2015) Thermodynamic Evaluation of Solar Integration into a Natural Gas Combined Cycle Power Plant. Renewable Energy, 74, 815-824.

[18] Schwarzbözl, P., et al. (2006) Solar Gas Turbine Systems: Design, Cost and Perspectives. Solar Energy, 80, 1231-1240. https://doi.org/10.1016/j.solener.2005.09.007

[19] https://news.energysage.com/what-are-the-most-efficient-solar-panels-on-the-mark et

[20] Neises, T. and Wagner, M.J. (2013) Simulation of Direct Steam Power Tower Concentrated Solar Plant. 6th International Conference on Energy Sustainability Collocated with the ASME 201210 th International Conference on Fuel Cell Science, Engineering and Technology, San Diego, 23-26 July 2012, 499-507. https://doi.org/10.1115/ES2012-91364

[21] https://new.siemens.com/global/en/products/energy/power-generation/gas-turbines /sgt-100.html

[22] Wang, S.C., et al. (2019) Performance Prediction of the Combined Cycle Power Plant with Inlet Air Heating under Part Load Conditions. Energy Conversion and Management, 200, Article ID: 112063.

https://doi.org/10.1016/j.enconman.2019.112063

[23] Alqahtani, B.J. and Patiño-Echeverri, D. (2016) Integrated Solar Combined Cycle Power Plants: Paving the Way for Thermal Solar. Applied Energy, 169, 927-936. 


\section{Appendix A}

\section{A.1. Heat Recovery Steam Generator (HRSG)}

Heat balance equation between gas turbine and HRSG

$$
\begin{gathered}
m_{s}\left(h_{1}-h_{4}\right)=m_{e g} * C_{p g}\left(T_{d}-T_{a}\right) \\
m_{s}\left(h_{5}-h_{4}\right)=m_{e g} C_{p g}\left(T_{x}-T_{a}\right)
\end{gathered}
$$

Economiser

$$
Q_{e c}=Q_{e g, e c} * m_{e g}=m_{s}\left(h_{5}-h_{4}\right)
$$

Evaporator

$$
Q_{e v}=Q_{e g, e v} * m_{e g}=m_{s}\left(h_{6}-h_{5}\right)
$$

Superheater

$$
m_{s}\left(h_{5}-h_{4}\right)=m_{e g} C_{p g}\left(T_{x}-T_{a}\right)
$$

Heat Rejected by exhaust gas

$$
Q_{s h}=Q_{e g, s h} * m_{e g}=m_{s}\left(h_{1}-h_{6}\right)
$$

HRSG capacity

$$
Q_{H R S G}=Q_{e c}+Q_{e v}+Q_{s h}
$$

\section{A.2. Levelized Cost of Electricity (LCOE) Calculation}

LCOE cents/kWh for all the technologies considered in this study calculated using the following equation.

$$
\mathrm{LCOE}=\frac{C C_{\text {annual }}+O \& M_{\text {annual }}+F C_{\text {annual }}}{E_{\text {annual }}}
$$

$C C_{\text {annual }}=$ the total annualized capital cost (\$).

$O \& M_{\text {annual }}=$ annual operational \& maintenance cost - both fixed and variable.

$F C_{\text {annual }}=$ the annual fuel expenses (\$).

$E_{\text {annual }}=$ the annual electricity generation (MWh).

\section{A.3. Thermodynamic Cycles}

The structure of a combined cycle is based on two thermodynamic cycles. The Brayton cycle is the top cycle which supplies its waste energy to a bottom cycle known as the Rankine cycle. Figure A1 shows how the Brayton cycle energy is used to provide energy to the Rankine cycle [10]. Figure A2 shows a T-s diagram for the combined cycle system.

\section{A.3.1. Brayton Cycle}

The ideal Brayton cycle consists of two isobaric and two isentropic processes. The two isobaric processes are the combustion chamber of gas turbine and heat recovery steam generator, whereas the two isentropic processes are compressor and turbine. Figure A3 shows the ideal Brayton cycle on a PV and T-s diagram. 


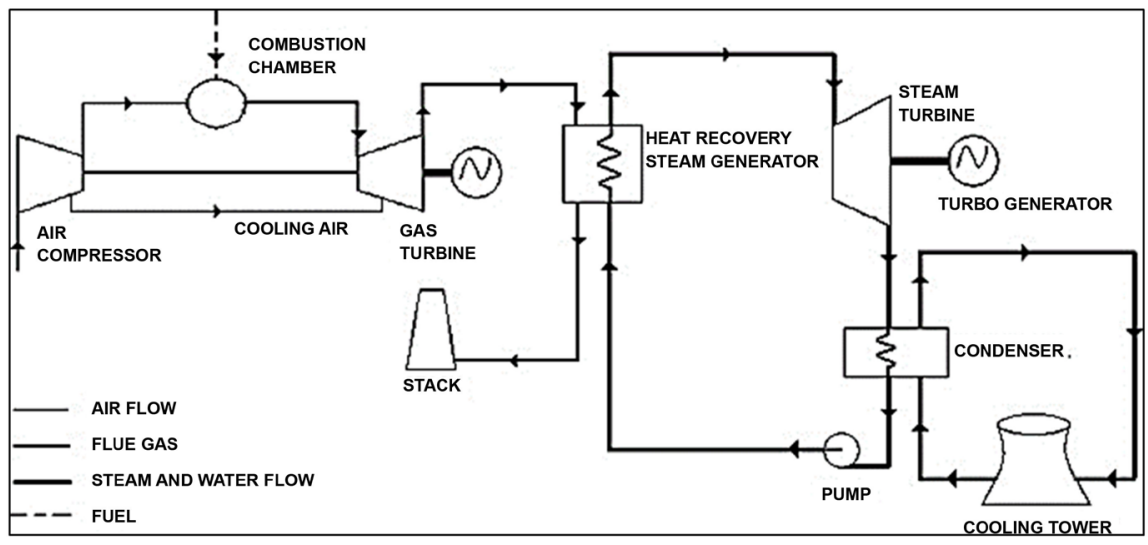

Figure A1. Combined cycle power plant.

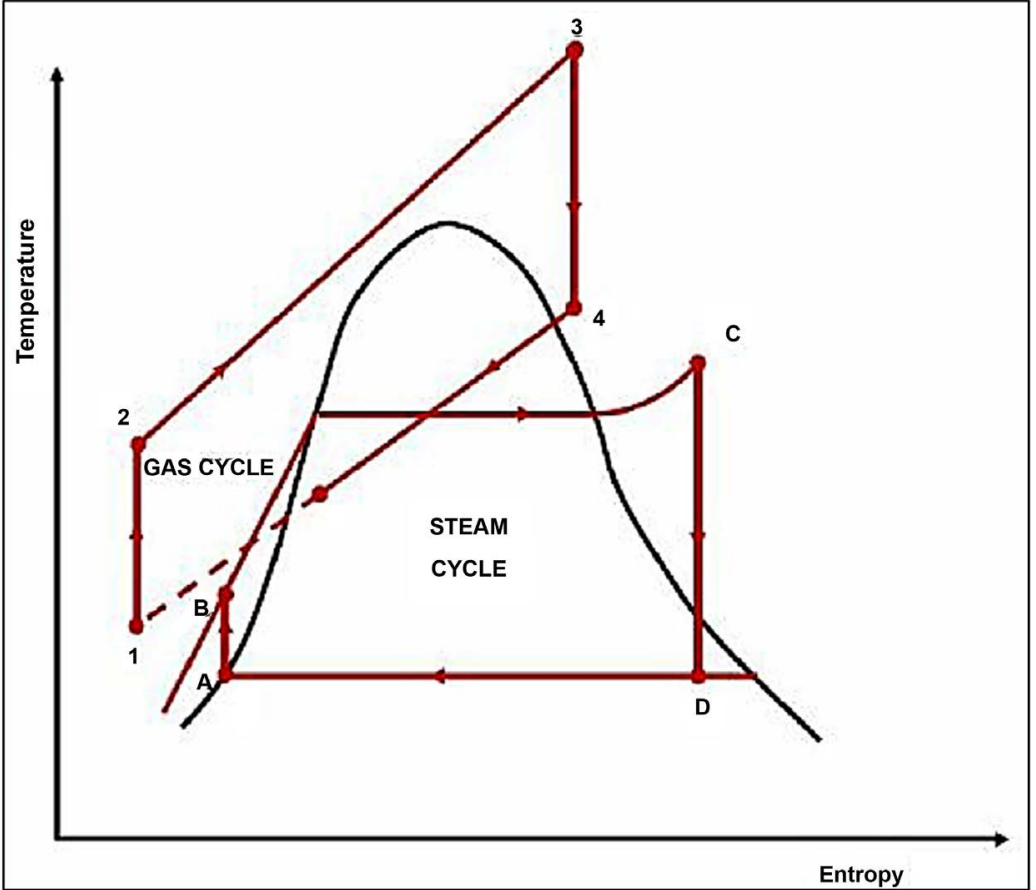

Figure A2. Combined cycle T-s diagram.

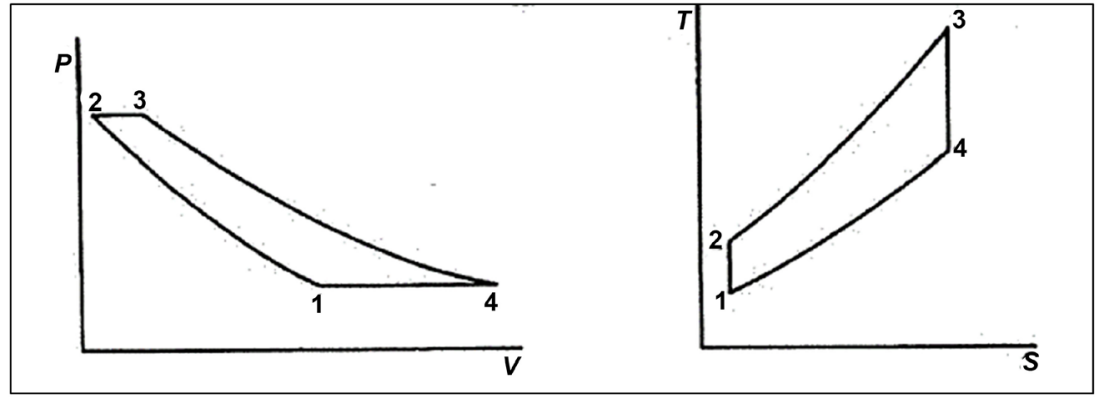

Figure A3. T-s and p-v diagram of Brayton cycle.

From 0 - 1 air intake takes place from the environment. From 1 - 2 the compression process takes place in a compressor. From $2-3$, the combustion process 
takes place in which heat is added and pressure is kept constant. From 3 - 4, isentropic expansion takes place in the turbine. From 4 - 5, exhaust gas from the gas turbine sent to the environment or HRSG for a regenerative process. By increasing the pressure ratio and turbine inlet temperature the efficiency of the Brayton cycle is increased.

The efficiency of the Brayton cycle is calculated based on a few assumptions:

- The mass flow rate of air should be greater than fuel mass flow rate $m_{a} \gg m_{f}$.

- Fuel is calorically perfect, which indicates the specific heat at constant pressure and constant volume is kept constant, thus the specific heat is kept constant throughout the process.

- The pressure ratio of the compressor and turbine are the same.

- There are no pressure drops.

- All the components efficiency is $100 \%$

Work of a compressor: $W_{c}=m_{a}\left(h_{2}-h_{1}\right)$

Work of a Turbine: $W_{c}=\left(m_{a}+m_{f}\right)\left(h_{3}-h_{4}\right)$

Total work output: $W_{\text {Total }}=W_{t}-W_{c}$

Heat added to the system: $Q_{2,3}=\left(m_{a}+m_{f}\right) h_{3}-m_{a} h_{2}$

Efficiency of Brayton cycle: $\eta_{\text {cycle }}=\frac{W_{\text {Total }}}{Q_{2,3}}$

For the actual Brayton cycle, by considering the effect of compressor efficiency and turbine efficiency and by considering the fuel temperature and ambient air temperature, the overall efficiency of the actual Brayton cycle can be calculated as shown in the equation below which shows the overall efficiency of the actual Brayton cycle.

$$
\eta_{c y c l e}=\left(\frac{\left(\eta_{t} * T_{f}\right)-\frac{T_{a m b} * r_{p}^{\left(\frac{\gamma-1}{\gamma}\right)}}{\eta_{c}}}{T_{f}-T_{a m b}-T_{a m b}\left(\frac{r_{p}^{\left(\frac{\gamma-1}{\gamma}\right)}-1}{\eta_{c}}\right)}\right) *\left(1-\frac{1}{r_{p}^{\left(\frac{\gamma-1}{\gamma}\right)}}\right)
$$

\section{A.3.2. Rankine Cycle}

The ideal Rankine cycle as shown in Figure A4 consists of four processes; from $1-2$ is isentropic compression process where the pressure is increased and the water is pumped to the HRSG. From 2-3 heat addition takes place in the boiler or HRSG at constant pressure. From 3-4 isentropic expansion in the turbine takes place. From 4-1 heat rejection in the condenser takes place and the steam is condensed under constant pressure.

Power generated by the turbine: $W_{S T}=m_{s}\left(h_{3}-h_{4}\right)$

Power consumption by the pump: $W_{p}=m_{w}\left(h_{2}-h_{1}\right)$

Net work done by the Rankine cycle: $W_{\text {Total }}=W_{S T}-W_{p}$

Heat added by the cycle: $Q=m_{s t}\left(h_{3}-h_{2}\right)$ 


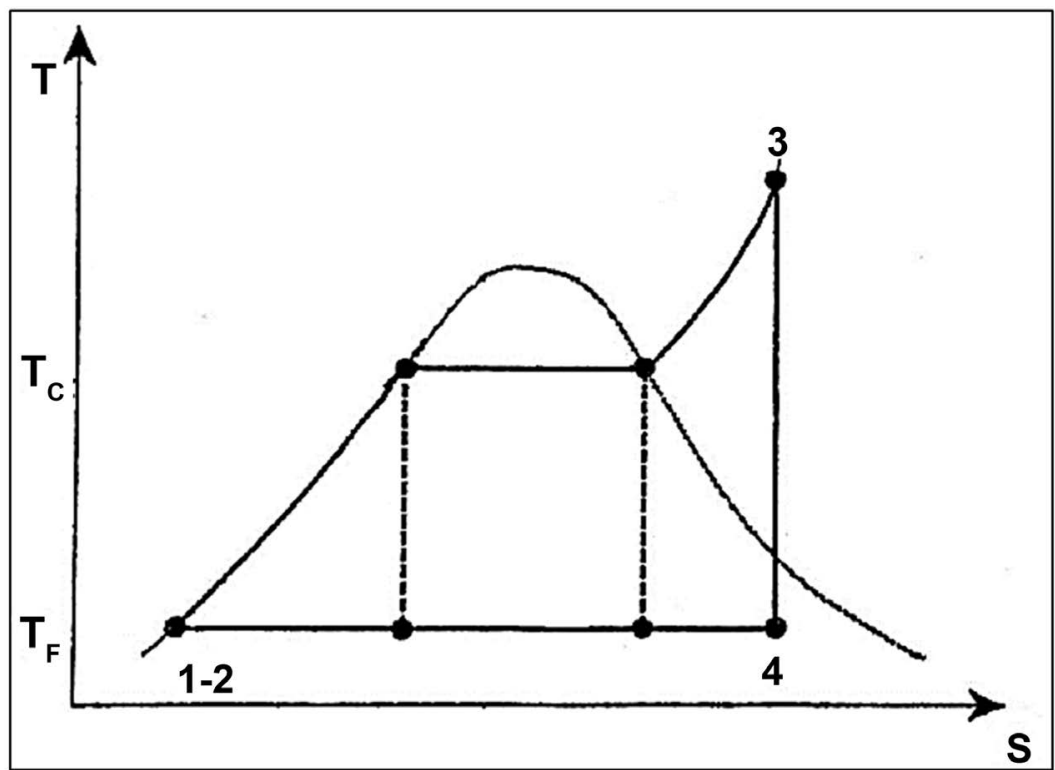

Figure A4. Rankine cycle.

Efficiency of the Rankine cycle: $\eta_{\text {cycle }}=\frac{W_{\text {Total }}}{Q_{\text {in }}}=\frac{\left(h_{3}-h_{4}\right)-\left(h_{2}-h_{1}\right)}{h_{3}-h_{2}}$

\section{A.3.3. Heat Recovery Steam Generator (HRSG)}

The primary function of the heat recovery steam generator (HRSG) is to use the waste heat from the gas turbine to generate steam at the desired condition to drive the steam turbine. As stated earlier, the components and working of HRSG consist of an economizer, evaporator, and superheater as earlier in Figure 9. The HRSG is commonly classified based on heat input, design and pressure operation. Figure A5 is a temperature-energy diagram showing variation of energy available from the HRSG as a function of temperature.

An HRSG can be classified as fired or unfired heat input. Usually, the HRSG doesn't require any additional heating and its efficiency is based on the temperature of flue gas from the gas turbine outlet. The variation in ambient conditions can affect the exhaust temperature of the gas turbine and then might result in supplemental heat being required to maintain the efficiency of steam production. The supplementary heat addition is done in the inlet section of HRSG. The supplementary heat is supplied by oil or gas, as there is no need for additional air supply because the flue contains a high amount of oxygen.

In design terms, HRSG can be classified as a horizontal or vertical type. A Horizontal type HRSG consists of a horizontal duct for gas turbine flue gas with the exchange pipes operating perpendicular to the flow. Heat transfer takes place by normal circulation. Whereas, in the vertical type, the high-temperature flue gas flows vertically and the exchange pipes are kept horizontal. Both types have their limitations. Horizontal types require 30 percent more space, maintenance is difficult, and more expansion joints are needed for this type. In vertical type, the structural requirements are greater. 


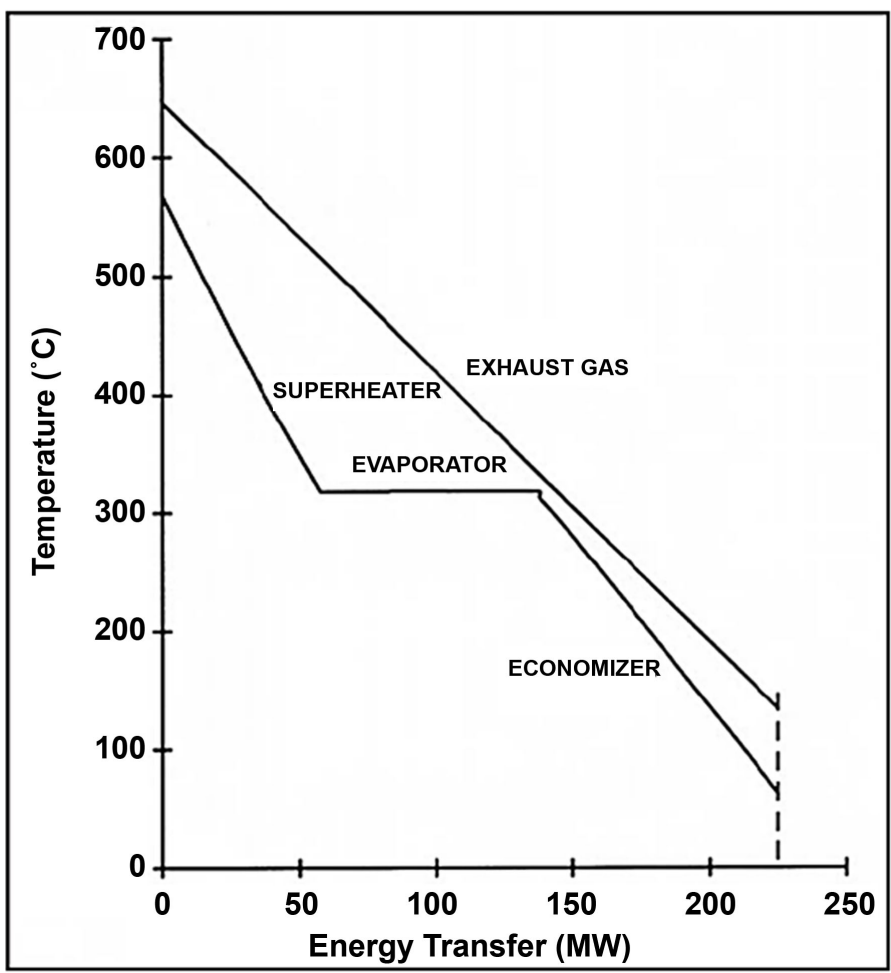

Figure A5. Temperature-energy diagram for single pressure HRSG.

Also, an HRSG can be listed as a single pressure or a multi-pressure unit. The type used is determined based on the plant size. For small size power plants the single pressure HRSG can fulfill the requirement. For larger power plants, the multi-pressure HRSG would be preferred. In general, the construction of a single pressure HRSG consists of an economizer, evaporator, and superheater. For a multi-pressure unit the pressure level varies depending on the power requirements. For example, a duel pressure HRSG has an economizer, evaporator, and superheater in both the high pressure and low-pressure level.

The pinch point and approach point are important parameters in an HRSG where both points define the steam generation. By decreasing the temperature for both points, the power output of the steam turbine is increased by utilizing the flow rate into the HRSG. The cost of the HRSG increases as the temperature of the pinch and approach point decreases. The pressure drop in HRSG results in a higher pressure and temperature in the evaporator section which results in less energy produced in the steam generator. The pressure drop doesn't affect the economizer section, but it affects the power consumed by feedwater pumps. While designing an HRSG the exhaust pressure from the gas turbine should be kept as low as possible. By maintaining low pressure, the back pressure in the gas turbine increases which results in a decrease in power output by decrease in the enthalpy change. A low-pressure operation results in low a gas velocity, which will affect the flow around the tube and decrease the heat transfer in the HRSG. 